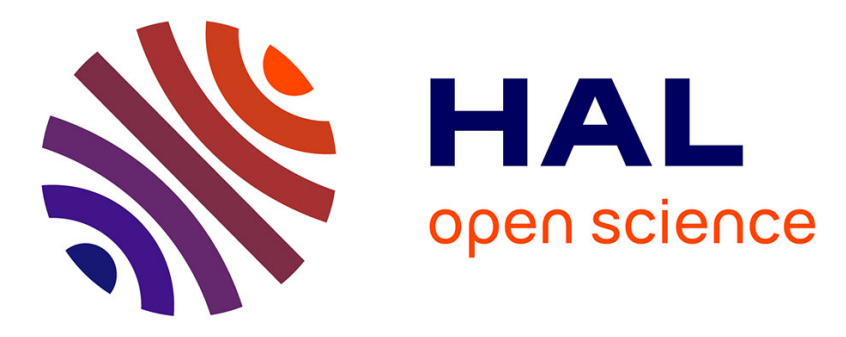

\title{
Waste fibre-cement matrix bond characteristics improved by using silane-treated fibres
}

Mahfoud Benzerzour, Nassim Sebaibi, Nor Edine Abriak, Christophe Binetruy

\section{To cite this version:}

Mahfoud Benzerzour, Nassim Sebaibi, Nor Edine Abriak, Christophe Binetruy. Waste fibre-cement matrix bond characteristics improved by using silane-treated fibres. Construction and Building Materials, 2012, 37, pp.1-6. 10.1016/j.conbuildmat.2012.07.024 . hal-01007431

\section{HAL Id: hal-01007431 https://hal.science/hal-01007431}

Submitted on 9 Mar 2018

HAL is a multi-disciplinary open access archive for the deposit and dissemination of scientific research documents, whether they are published or not. The documents may come from teaching and research institutions in France or abroad, or from public or private research centers.
L'archive ouverte pluridisciplinaire HAL, est destinée au dépôt et à la diffusion de documents scientifiques de niveau recherche, publiés ou non, émanant des établissements d'enseignement et de recherche français ou étrangers, des laboratoires publics ou privés. 


\title{
Waste fibre-cement matrix bond characteristics improved by using silane-treated fibres
}

\author{
Mahfoud Benzerzour a , Nassim Sebaibi a,b,*, Nor Edine Abriak ${ }^{\mathrm{a}}$, Christophe Binetruy ${ }^{\mathrm{b}, \mathrm{c}}$ \\ ${ }^{a}$ Ecole des Mines de Douai, Civil Engineering and Environnemental Department, 941 rue Charles Bourseul, 59508 Douai Cedex, France \\ ${ }^{\mathrm{b}}$ Ecole des Mines de Douai, Polymer and Composites Technology and Mechanical Engineering Department, 941 rue Charles Bourseul, BP 10838,58508 Douai Cedex, France \\ ${ }^{\mathrm{c}}$ Ecole Centrale de Nantes, Research Institute in Civil Engineering and Mechanics (GeM), 1 rue de la Noë 44321 NANTES, France
}

\begin{abstract}
In this paper, the effects of silane treatment on the bond characteristics of fibre in a cementitious matrix, including the bond strength, pullout energy, etc., are presented. These fibres were obtained from recycling by crushing of a thermoset composite based on unsaturated polyester/glass fibre. The experimental results of the fibre pullout test under different conditions are reported. Silane treatment contents between $0 \%$ and $1 \%$ are used, and single fibre pullout tests are conducted to measure the bond characteristics of the fibre to the cementitious matrix. It is found that the silane treatment (VTMO) can effectively enhance the fibre-matrix interfacial properties, especially the fibre pullout energy. It is also concluded that in terms of the bond characteristics, the optimal silane content is $0.5 \%$, given the conditions of this experimental program. Microstructural observation confirms the findings on the interfacial-toughening mechanism drawn from the fibre pullout test results.
\end{abstract}

Keywords: Silane, Microstructure, Bond strength, Pullout strength, Interfacial transition zone, Pullout energy

\section{Introduction}

Fibres are added to concrete to increase the tensile and flexural strengths, increase the tensile ductility and flexural toughness, decrease the drying shrinkage and impart the concrete with the ability to sense its own strain [1,2]. The final mechanical behaviour of a composite material depends to a great extent on the adhesion between the reinforcing fibre and the surrounding matrix. The adhesion between two different materials is a function of several factors, among which are the surface roughness and surface polarity [3]. Measurements of the surface energies and bond strength can give an idea of the interfacial adhesion between the fibre and the matrix.

* Corresponding author at: Ecole des Mines de Douai, Civil Engineering and Environnemental Department, 941 rue Charles Bourseul, 59508 Douai Cedex, France. Tel.: +33 327712 427; fax: +33 327712916 .

E-mail address: nassim.sebaibi@hotmail.fr (N. Sebaibi).
The fibres used in this research come from the recycling of thermoset composite materials (unsaturated polyester/glass fibres). The fibres are treated with vinyl trimethoxy silane agents (VTMO) to improve the bond characteristics of the interfacial zone between the waste fibres and the cement matrix.

However, to effectively couple the fibres and matrices, the silane molecule should have bifunctional groups that can react with the two phases, thereby forming a bridge between them. Silane coupling agents have a generic chemical structure $R_{(4-n)}-S_{i}-\left(R^{\prime} X\right)_{n}$ ( $n=1,2)$ where $R$ is an alkoxy group, $X$ represents an organofunctionality, and $R^{\prime}$ is an alkyl bridge (or alkyl spacer) connecting the silicon atom and the organofunctionality. The organofunctionality of the silane interacts with the matrix, and the mode of interaction depends on the reactivity of the functionality or its compatibility with the polymer [4]. A nonreactive alkyl group of the silane may increase its compatibility with a non-polar matrix because of their similar polarities; however, a reactive organofunctionality may covalently bond with, as well as being physically compatible with, the polymer matrix. These organofunctionalities 
of silanes are typically amino, mercapto, glycidoxy, vinyl, or methacryloxy groups.

Vinyl- and acryl-silanes are coupling agents that are able to establish covalent bonds with polymeric matrices in the presence of peroxide initiators. Alkoxy silanes have been demonstrated to be able to react directly with the $-\mathrm{Si}-\mathrm{OH}$ groups of silica, thereby forming $-\mathrm{Si}-\mathrm{O}-\mathrm{Si}-$ bonds without any requirement of prehydrolysis [5-7]. However, silanes do not undergo the same reaction with the hydroxyl groups of cellulosic fibres, even at high temperatures [8]. This difference has been attributed to the lower acidity of the cellulosic hydroxyl groups compared with those of silanol [8]. In addition, cellulose is generally unreactive to many chemicals, and the $\mathrm{OH}$ groups of the microfibrils have very low accessibility. Based on this fact, one possible strategy is to activate the alkoxysilane by hydrolysing off the alkoxy groups, thereby forming more reactive silanol groups. As a result, the silanol groups may react with the hydroxyl groups of the fibres or condense themselves on the surfaces of the fibres or in the cell walls, forming a macromolecular network. Although the formed $-\mathrm{Si}-\mathrm{O}-\mathrm{C}-$ bonds are eventually unstable toward hydrolysis, blocking the hydroxyl groups (reversible to hydrolysis) and forming a macromolecular network (permanent) under heating enhances the interfacial adhesion of the treated fibres and the polymer matrix, as well as the properties of the resulting composites. To hydrolyse the alkoxy groups, the participation of water is essential. Although the fibres under ambient condition contain bound water that may act to hydrolyse the silanes, additional water is required to achieve their complete hydrolysis $[9,10]$.

In the presence of water, the silane undergoes a hydrolysis process. Alkoxysilanes are hydrolysed, forming alkoxysilanol mono-, di- and eventually silane triols. To fully hydrolyse one mole of trialkoxysilane, at least three moles of water are needed. Once the silanol groups form in the solution, the condensation between silanol groups also starts, thereby generating a siloxane $(-\mathrm{Si}-\mathrm{O}-\mathrm{Si}-)$ polymer network in the solution. Thus, the sol evolves towards the formation of a gel-like diphasic system containing both a liquid phase and solid phase, whose morphologies range from discrete particles to continuous polymer networks. The competition of alkoxy hydrolysis and silanol condensation is affected by the hydrolysis conditions, such as the solvent, temperature, $\mathrm{pH}$, and concentration of silanes $[11,12]$. Under optimal conditions, hydrolysis may be accelerated, but the condensation of silanols is inhibited, maintaining stable intermediary structures such as silanol monomers or dimers $[11,13,14]$.

In this work, the fibres were subjected to surface treatment by vinyl trimethoxy silane (VTMO) to improve the adhesion between the fibres and the matrix. Then, the bond characteristics of the fibres in a cementitious matrix were investigated by fibre pullout tests, with the silane content as the primary variable of the experimental program.

\section{Experimental program}

\subsection{Materials}

The materials used for the cementitious matrix were selected for high compactness in the cement and silica fume and a strong deflocculating power for the superplasticizer:

- Portland cement CEM I $52.5 \mathrm{~N}$, supplied by Holcim.

- Silica fume powder with $93 \% \mathrm{SiO}_{2}$, supplied by ELKEM Company from Norway.

- Glenium ACE 30 super-plasticizer, supplied by B.A.S.F. Glenium ACE 30

- Sand with a size grading of $125-400 \mu \mathrm{m}$, supplied by Sifraco.

- Recycled fibres (unsaturated polyester/glass fibres): the fibres used were commercially available under the name RECY FIB-100 and are produced by MCR (Mixt Composite Recyclables, TOURNON, France). Their density, measured by means of a pycnometer with helium, was $1.873 \mathrm{~g} \mathrm{~cm}^{-3}$, and their lengths ranged from 0.4 to $23 \mathrm{~mm}$. The fibres were treated with vinyl trimethoxy silane (VTMO), from Degussa-Hüls with a density of 0.97 .
Table 1

Physical properties and chemical composition of cement and silica fume.

\begin{tabular}{lll}
\hline $\begin{array}{l}\text { Properties } \\
\text { Type }\end{array}$ & $\begin{array}{l}\text { Cement } \\
\text { CEM I 52.5 N }\end{array}$ & $\begin{array}{l}\text { Silica fume } \\
\text { Elkem 940U }\end{array}$ \\
\hline $\begin{array}{l}\text { Physical properties } \\
\text { Specific gravity }\end{array}$ & & \\
Surface area, Blaine $\left(\mathrm{cm}^{2} / \mathrm{g}\right)$ & 3.13 & 2 \\
Chemical analysis & 3800 & 250 \\
$\mathrm{SiO}_{2}$ & & \\
$\mathrm{Al}_{2} \mathrm{O}_{3}$ & 18.7 & 93 \\
$\mathrm{Fe}_{2} \mathrm{O}_{3}$ & 5.7 & 0.2 \\
$\mathrm{CaO}_{\mathrm{MgO}}$ & 3.9 & 0.05 \\
$\mathrm{SO}_{3}$ & 63.1 & - \\
$\mathrm{Na}_{2} \mathrm{O}$ & 0.8 & 0.51 \\
$\mathrm{~K}_{2} \mathrm{O}$ & 3.3 & 0.05 \\
& 0.42 & 0.2 \\
& 0.77 & 0.22 \\
\hline
\end{tabular}

Table 2

Formulation of cementitious matrix.

\begin{tabular}{ll} 
Cement $\left(\mathrm{kg} / \mathrm{m}^{3}\right)$ & 1052 \\
Sand $\left(\mathrm{kg} / \mathrm{m}^{3}\right)$ & 770 \\
Silica fume $\left(\mathrm{kg} / \mathrm{m}^{3}\right)$ & 268 \\
Superplasticizer $\left(\mathrm{kg} / \mathrm{m}^{3}\right)$ & 50 \\
Total water $\left(1 / \mathrm{m}^{3}\right)$ & 230 \\
Water/cement & 0.21 \\
Water/binder & 0.17 \\
Superplasticizer/binder & 0.0113 \\
\hline
\end{tabular}

Table 3

Polymer content in the fibres.

\begin{tabular}{lll}
\hline & Mass of specimen $(\mathrm{g})$ & Polymer $(\%)$ \\
\hline Average & 4.8118 & 10.26 \\
Standard deviation & 0.23 & 0.79 \\
\hline
\end{tabular}

The physical properties and chemical analysis of the cement and silica fume are given in Table 1.

The composition of the cementitious matrix is given in Table 2. The cement sand and silica fume were first dry-mixed for $1 \mathrm{~min}$. The water and superplasticizer were then added and mixed for approximately $4 \mathrm{~min}$. The entire mixing process took approximately 5 min before the cementitious matrix was ready to cast.

\subsection{Chemical and physical properties of fibres}

In these measurements, the exact glass, calcium carbonate and unsaturated polyester contents of the fibres were determined.

\subsubsection{Calcinations}

The amount of polymer in the fibres was determined by calcination. Approximately $5 \mathrm{~g}$ of fibre was placed in a furnace at $500{ }^{\circ} \mathrm{C}$ for $3 \mathrm{~h}$. The weight difference before and after the heat treatment gave the mass of the polymer and the percent composition was calculated. Table 3 shows the average percentage of polymer from three tests.

\subsubsection{Calcimetry}

This section is based on the use of a Bernard Calcimeter. This method has been studied and developed by multiple authors $[15,16,19]$. The assay quantifies the $\mathrm{CO}_{2}$ released when the sample is treated with hydrochloric acid. In a closed system, under a constant pressure and temperature, if there are no other gases involved, the quantity of $\mathrm{CO}_{3}^{-2}$ is directly proportional to the volumetric increase resulting from the release of $\mathrm{CO}_{2}$.

The chemical reaction that occurs is:

$\mathrm{CaCO}_{3(\mathrm{~s})}+2 \mathrm{HCl}_{(\mathrm{l})} \leftrightarrow \mathrm{CO}_{2(\mathrm{~g})}+\mathrm{H}_{2} \mathrm{O}_{(\mathrm{l})}+\mathrm{CaCl}_{2}$

The calibration of the apparatus was performed using pure calcite crystals reduced to a fine powder. Tests were performed with various amounts of powder to obtain precise results. The uncertainty of the measurements was caused by the variation of the pressure and temperature. In order to verify the reproducibility of the results, 12 tests were performed to find the percentage of $\mathrm{CaCO}_{3}$, which was obtained by the following relation: 
Table 4

Calcium carbonate content in fibres.

\begin{tabular}{llll}
\hline & $m_{\text {fibres }}(\mathrm{g})$ & $V\left(\mathrm{CO}_{2}\right)(\mathrm{ml})$ & $\mathrm{CaCO}_{3}(\%)$ \\
\hline Average (\%) & 0.7491 & 76.45 & 55.50 \\
Standard deviation & 0.1023 & 8.16 & 3.13 \\
\hline
\end{tabular}

$\% \mathrm{CaCO}_{3}=\frac{m_{\left(\mathrm{CaCO}_{3}\right)} \cdot V\left(\mathrm{CO}_{2}\right)_{\text {fibres }} \cdot\left(\theta_{\text {fibres }}+273\right)}{m_{\text {fibres }} \cdot V\left(\mathrm{CO}_{2}\right)_{\text {Calibrate }} \cdot\left(\theta_{\text {Calibrate }}+273\right)} \times 100$

$m\left(\mathrm{CaCO}_{3}\right)$ is the mass of pure calcium carbonate weighed for calibration $(\mathrm{g})$, $V\left(\mathrm{CO}_{2}\right)_{\text {Calibrate }}$ the volume of $\mathrm{CO}_{2}$ released by calcium carbonate $(\mathrm{ml}), m_{\text {fibres }}$ the mass of the fibres $(\mathrm{g}), V\left(\mathrm{CO}_{2}\right)_{\text {fibres }}$ the volume of $\mathrm{CO}_{2}$ released by the fibres $(\mathrm{ml}), \theta$ is the temperature in degrees Celsius $\left({ }^{\circ} \mathrm{C}\right)$.

The percentage of $\mathrm{CaCO}_{3}$ content in the fibres is given in Table 4.

Combining these two techniques (calcination and calcimetry), we were able to determine the glass fibre content present in the fibres. The amount of the material composed of glass fibre was calculated by use of the following relationship:

Glass fibres (\%) : $100 \%-\left(\% \mathrm{CaCO}_{3}-\%\right.$ Polyesters $)$ which constitute $35 \%$

\subsection{Fibre treatments}

For the surface treatment of the fibre, various contents of silane $\left(\mathrm{CH}_{3}-\mathrm{O}\right)_{3} \mathrm{Si}-\mathrm{CH}=\mathrm{CH}_{2}(0.5 \%, 0.75 \%$ and $1 \%$ of silane by weight as a percentage of fibre weight) were dissolved for hydrolysis in a mixture of methanol and water. The $\mathrm{pH}$ of the solution was adjusted to 3.5 with acetic acid and stirred continuously for $30 \mathrm{~min}$ to ensure a better reaction. Then, the fibres were immersed in the solution and left for $1 \mathrm{~h}$ under agitation. Finally, the fibres were dried at $80^{\circ} \mathrm{C}$ for $30 \mathrm{~min}$.

Table 5 summarizes the mixture proportions for each fibre treatments.

\subsection{Specimen preparation}

A prismatic shape mould was used $(10 \times 10 \times 20 \mathrm{~mm})$ to prepare the fibre pullout specimens. To ensure that the fibres were fixed in one half and will be pulled out from the other half of the mould, glue was used on the end of the fibre to it from sliding at the level of the upper bit.

In total, 28 samples were prepared with various levels of silane content ( $0 \%, 0.5 \%, 0.75 \%$ and $1 \%)$ to study the pullout behaviour.

After preparation of the cementitious matrix, the sample was demolded $24 \mathrm{~h}$ after the casting of the pullout half of the sample and cured for 7 days prior to the test. The conditions for curing were set at a constant $20^{\circ} \mathrm{C}$ and $50 \% \mathrm{RH}$ until testing.

\subsubsection{Pullout test setup}

Fig. 1 shows the specimen fixtures of the pullout test setup on the Dynamics Mechanical Analysis (DMA). The pullout load is estimated to be in the range of $5-30 \mathrm{~N}$ for the untreated fibres. The capacity of the load cell adopted in this test is $100 \mathrm{~N}$ and after several tests, the pullout is conducted in a loading rate of $0.016 \mathrm{~N} / \mathrm{s}$.

\section{Results and discussions}

\subsection{Fibre pullout behaviour}

The curves describing the pullout behaviour for various silane contents are presented in Fig. 2. In our case, we cannot base our discussion on the pullout load, because the fibre length is not uniform section. Thus, the interfacial bond strength is used as the comparable quantity.

\subsection{Interfacial bond strength}

The frictional stress depends on the pull-out behaviour of the fibres in the matrix and can be determined by the maximum pullout load, $P_{\max }$, divided by the surface area of the fibre exposed to the frictional stress action, $A_{f}$ :

$\tau_{\max }=\frac{P_{\max }}{A_{f}}$,

and $A_{f}$ can be determined by:

$A_{f}=n \cdot \pi \cdot D \cdot L$

where $\tau_{\max }$ is the bond strength or maximum shear stress, $P_{\max }$ is the maximum pullout load, $n$ is the number of embedded fibres, $D$ is the diameter and $L$ is the embedment length of the fibre.

To estimate the interfacial bond strength, we must find the number of fibres embedded in the matrix, which can be determined from the microscope observation of the fibres after the pullout test.

The effects of the silane treatment on the fibre bond strength have been reported, including the debond mode and the measured bond strength $[17,18]$. It has been found that the silanization has

Table 5

Mix proportion of fibres treatments (weight ratio).

\begin{tabular}{|c|c|c|c|c|c|}
\hline Silane content (wt.\%) & Water & Fibres & Methanol & Acetic acid & Silane (VTMO) \\
\hline 0.5 & 1 & 0.042 & 0.01 & 0.01 & 0.0049 \\
\hline 0.75 & 1 & 0.042 & 0.01 & 0.01 & 0.0075 \\
\hline 1 & 1 & 0.042 & 0.01 & 0.01 & 0.01 \\
\hline
\end{tabular}
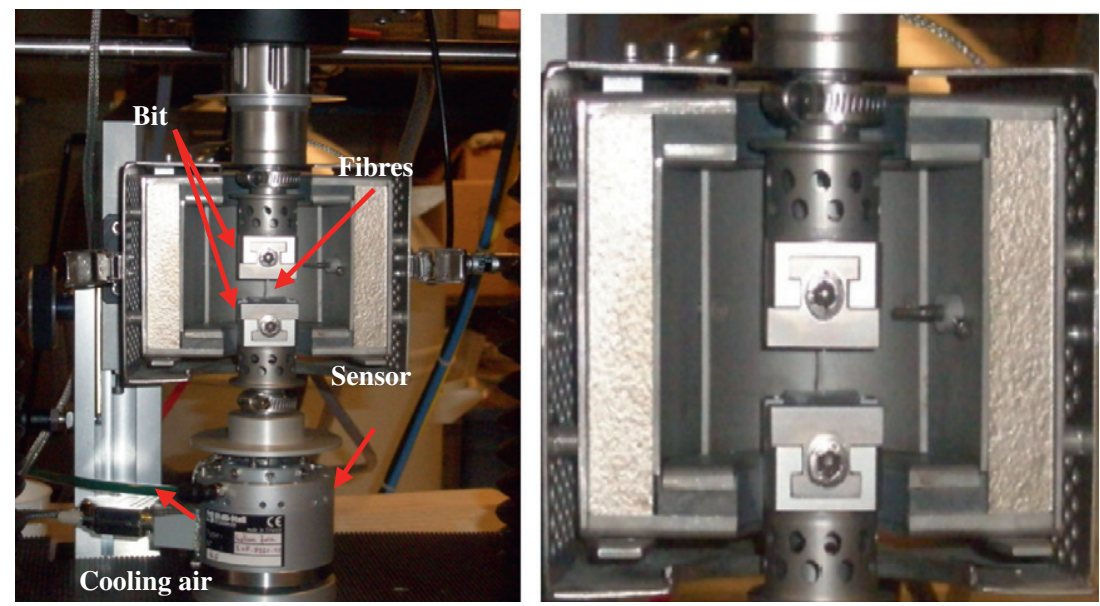

Fig. 1. Pullout test configuration. 


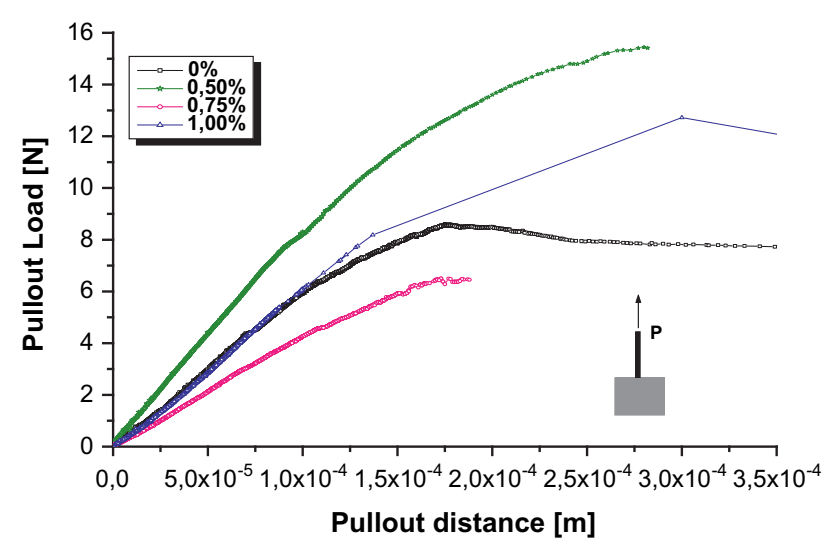

Fig. 2. Characteristics of fibre pullout curves for matrices with various silane contents.

changed the fibre debond mode from strength-based to fracturebased, which is consistent with the interfacial-toughening mechanism observed in this experimental investigation.

The maximum bond strength is interpreted and summarized in Table 6 and Fig. 3. It can be seen that the bond strength increases with the increase in silane (VTMO) content, up to $0.5 \%$. The increase in bond strength, however, is substantial. The average bond strength obtained in this study ranges between 0.279 MPa for the untreated fibres and $0.7 \mathrm{MPa}$ for fibres treated which represents an increase of $150 \%$. In addition, the interfacial-toughening effect in the bond strength vanishes if the silane content is too high, which is the case for a concentration of $0.75 \%$.

\subsection{Pullout energy}

The silanization treatment of the fibres has a significant effect on the fibre pullout behaviour with respect to pullout energy. The pullout energy is defined as the mechanical energy consumed during the fibre pullout process, and it can be obtained by integrating the area under the fibre pullout curve. In this investigation, the pullout energy is defined as the integration of the bond stress and pullout distance based on the pullout curve, up to a pullout distance of $0.25 \mathrm{~mm}$. The results are summarized in Table 6 and Fig. 4. According to Fig. 4, the enhancement in the pullout energy due to silane is far more significant than that in bond strength. As compared to the test without silane, the pullout energy is more than $300 \%$ larger for the case of $0.5 \%$ silane.

The pullout energy thus defined possesses a better correlation to the fracture energy of fibre-reinforced cement-based materials. Therefore, it is verified that the treatment of fibres by silane can effectively enhance the fracture toughness of the composite materials. In terms of silane content for treatment, according to the results of this research, it is found that $0.5 \%$ silane content produces optimal results.

\subsection{Interfacial microstructures}

To further investigate the interfacial-toughening mechanism by the silane treatment, the microstructures of fibres with various

Table 6

Bond characteristics of fibre embedded with various silane treatments (in the percentage of the one with $0 \%$ silane content).

\begin{tabular}{lllll}
\hline Silane (wt.\%) & 0 & 0.5 & 0.75 & 1 \\
Bond strength (MPa) & 0.279 & 0.7 & 0.42 & 0.41 \\
Increasing percentage (\%) & - & 150 & 50 & 47 \\
Pullout energy (N mm) & 0.0434 & 0.1745 & 0.088 & 0.0781 \\
Increasing percentage (\%) & - & 303 & 105 & 0.81 \\
\hline
\end{tabular}

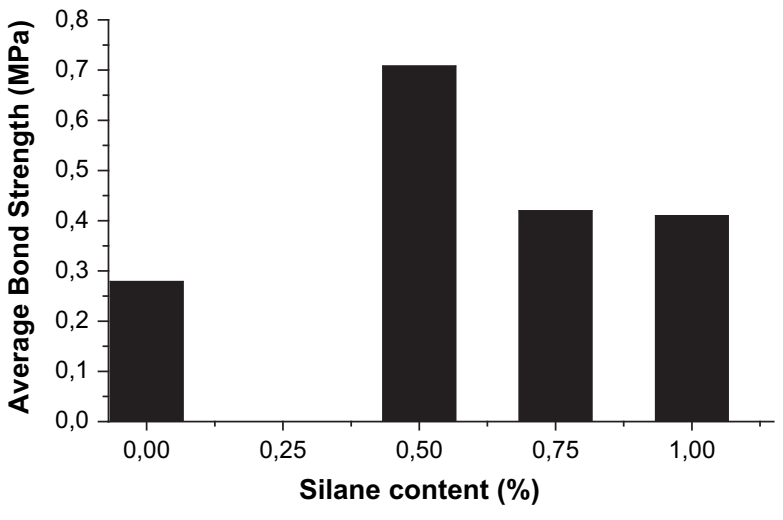

Fig. 3. Effect of silane treatment on bond strength.

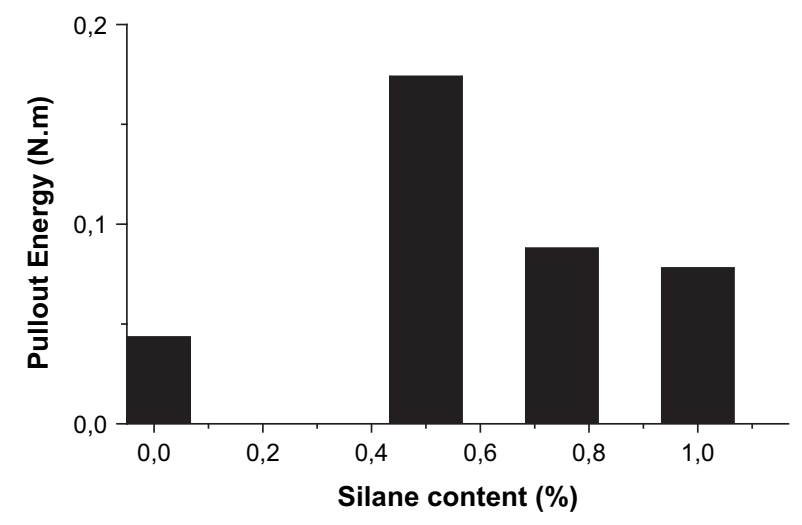

Fig. 4. Effect of silane treatment on pullout energy.

levels of silane content are observed. Fig. 5a shows the surface of a raw fibre that is not subjected to any abrasion. Fig. 5b shows a fibre pulled from the matrix without silane treatment, and Fig. 5c and $d$ show the surface morphology of fibres pulled from a matrix with $0.5 \%$ and $1 \%$ of silane, respectively. The fibres pulled from the matrices with substantial silane content have a dramatically different surface microstructure. As can be seen in Fig. $5 c$ and d, the fibre surface is coated with cementitious materials that have been partially destroyed or abraded. This may help to explain the remarkably high pull out load as observed samples treated by silane (Fig. 2).

The matrix adhering to the fibre can be worn during the pullout process and may accumulate near the fibre end. The accumulated matrix remnant in turn contributes to the resistance to the fibre pullout load. According to the observed microstructure, the cementitious remnants on the fibre surface are expected to enhance the friction and resistance. This effect may be further magnified by the increased diameter of fibre. Therefore, the greatly enhanced pullout energy is believed to be a reflection of this mechanism.

The experimental results presented in this paper have verified that the treatment of fibres with silane can remarkably enhance the fibre-matrix bond characteristics, especially the interfacialtoughening effect upon fibre slip. According to the effects of the bond strength and pullout energy measurements (Table 7), the beneficial effects of the treatment are obtained for an optimal ratio of $0.5 \%$, given the conditions of this experimental program. At this silane (VTMO) content, the pullout strength, bond strength and fibre pullout energy are the highest of all the cases tested. Although the increase of the bond strength is not significant in magnitude, the interfacial-toughening effect on fibre pullout is remarkable 

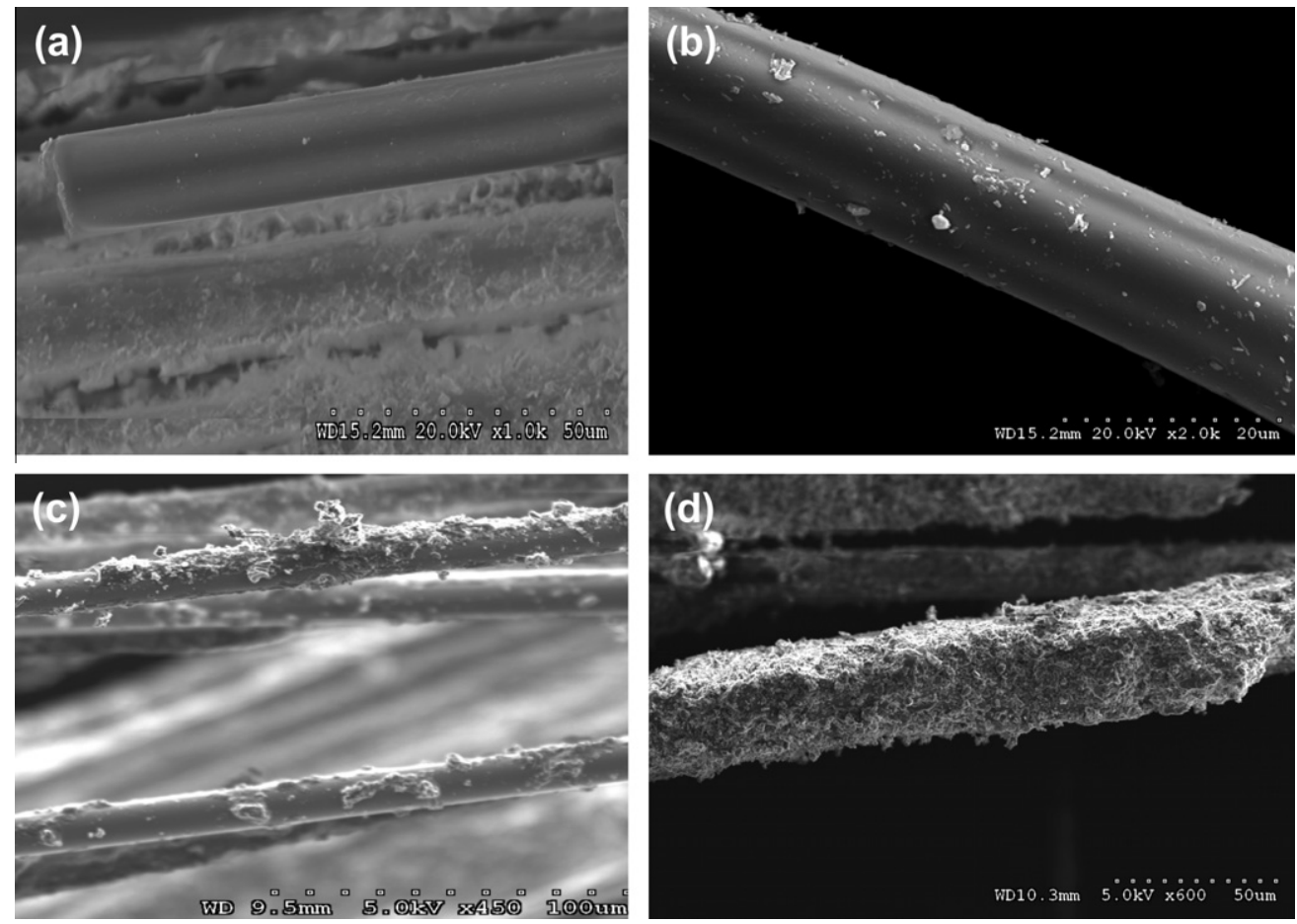

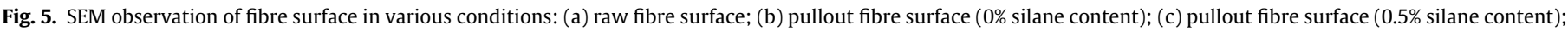
and (d) pullout fibre surface ( $1 \%$ silane content).

Table 7

Results of pullout energy measurement.

\begin{tabular}{|c|c|c|c|c|c|c|c|c|}
\hline \multirow[t]{2}{*}{ Silane content (wt.\%) } & \multicolumn{7}{|c|}{ Pullout energy $\left(\mathrm{N} \mathrm{mm}^{-1}\right)$} & \multirow[t]{2}{*}{ Average $\left(\mathrm{N} \mathrm{mm}^{-1}\right)$} \\
\hline & 1 & 2 & 3 & 4 & 5 & 6 & 7 & \\
\hline 0 & 0.0354 & 0.0145 & 0.0945 & 0.0248 & 0.047 & - & - & 0.0434 \\
\hline 0.5 & 0.0750 & 0.109 & 0.100 & 0.386 & 0.218 & 0.157 & - & 0.1741 \\
\hline 0.75 & 0.0973 & 0.0675 & 0.1012 & - & - & - & - & 0.0880 \\
\hline 1 & 0.06 & 0.090 & 0.124 & 0.0906 & 0.1 & 0.016 & 0.109 & 0.0781 \\
\hline
\end{tabular}

for silane treatment contents higher than $0.25 \%$. The pullout energy of the cases with silane content of $0.5 \%, 0.75 \%$ and $1 \%$ is more than three times that of the control case $(0 \%)$. This result is supported by the microstructural observation that the adhesion between the fibre and the cementitious matrix with various silane treatment contents is significantly improved. These findings provide further understanding of the fracture mechanism of Ultra High Performance Fibre Reinforced Concrete (UHPFRC). This information is especially helpful if UHPFRC is to be further improved through microstructural engineering.

\section{Conclusions}

The experimental results presented in this paper have verified that the incorporation of fibre treatment in the UHPC matrix remarkably enhances the fibre-matrix bond characteristics because of the interfacial-toughening effect upon fibre slip. The specific findings of this research include the following:

1. Based on the bond strength and pullout energy results, the optimal dosage of silane is $0.5 \%$, given the conditions of this experimental program. At this silane dosage, the bond strength, pullout strength, elastic modulus and fibre pullout energy are the highest among all cases.
2. Compared to that of the matrix without silane treatment, the enhancement of the pullout energy due to silane is more significant than that of bond strength. At the optimal silane dosage $(0.5 \%)$, the pullout energy is ten times that of the untreated fibres, while the bond strength is approximately three times that of the material with $0 \%$ silane content. The difference can be attributed to the different mechanisms of silane on pullout energy and on bond strength.

3. The microstructure of the fibres pulled out from the material with a high-content silane treatment reveals a great amount of cementitious material adhering to the fibre surface. Consequently, the cement matrix contributes to the friction and resistance during the fibre pullout process. Therefore, the pullout energy is remarkably enhanced when a fibre is treated by silane (VTMO).

\section{References}

[1] Sebaibi Nassim, Benzerzour Mahfoud, Abriak Nor Edine, Binetruy Christophe. Mechanical and physical properties of a cement matrix through the recycling of thermoset composites. Constr Build Mater 2012;34:226-35.

[2] Nassim Sebaibi. Valorisation des composites thermodurcissables issus du recyclage dans une matrice cimentaire: application aux bétons a ultra-haute performance. Thèse doctorat, Ecole des Mines de Douai; 2011. p. 187. 
[3] Yunsheng X, Chung DDL. Carbon fibre reinforced cement improved by using silane-treated carbone fibres. Cem Concr Res 1999;29:733-76.

[4] Yanjun Xie, Callum AS, Zefang X, Holger M, Carsten M. Silane coupling agents used for natural fibre/polymer composites: a review. Composites: Part A 2010:806-19.

[5] Plueddemann EP. Silane coupling agents. 2nd ed. New York and London: Plenum Press; 1991.

[6] Hertl W. Mechanism of gaseous siloxane reaction with silica. I. J Phys Chem 1968;72:3993-7.

[7] Krasnoslobodtsev AV, Smirnov SN. Effect of water on silanization of silica by trimethoxysilanes. Langmuir 2002;18:3181-4.

[8] Castellano M, Gandini A, Fabbri P, Belgacem MN. Modification of cellulose fibres with organosilanes: under what conditions does coupling occur? J Colloid Interf Sci 2004;273:505-11.

[9] Schneider MA, Brebner KI. Wood-polymer combinations: the chemical modification of wood by alkoxysilane coupling agents. Wood Sci Technol 1985;19:67-73.

[10] Salon MCB, Gerbaud G, Abdelmouleh M, Bruzzese C, Boufi S, Belgacem MN. Studies of interactions between silane coupling agents and cellulose fibres with liquid and solid-state NMR. Magnet Reson Chem 2007;45: 473-83.

[11] Díaz-Benito B, Velasco F, Martínez FJ, Encinas N. Hydrolysis study of bis-1,2(triethoxysilyl) ethane silane by NMR. Colloids Surf A: Physicochem Eng Aspects 2010;369:53-6.
[12] Riegel B, Blittersdorf S, Kiefer W, Hofacker S, Mueller M, Schottner G. Kinetic investigations of hydrolysis and condensation of the glycidoxypropyltrim ethoxysilane/amino propyltriethoxy - silane system by means of FT-Raman spectroscopy I. J Non-Cryst Solids 1998;226:76-84.

[13] Pohl ER, Osterholtz FD. Kinetics and mechanism of aqueous hydrolysis and condensation of alkyltrialkoxysilanes. In: Ishida $\mathrm{H}$, editor. Molecular characterization of composite interfaces. New York: Plenum Press; 1983.

[14] Pantoja M, Díaz-Benito B, Velasco F, Abenojar J, del Real JC. Analysis of hydrolysis process of c-methacryloxypropyltrimethoxysilane and its influence on the formation of silane coatings on 6063 aluminum alloy. Appl Surf Sci 2009;255:6386-90.

[15] Hulseman J. An inventory of marine carbonate materials. J Sedimentary Petrol ASCE 1966;36(2):622-5.

[16] Muller G, Gatsner M. Chemical analysis. Neues Jahrbuch fur Mineralogie Monatshefte 1971;10:466-9.

[17] Zhandarov S, Mâder E. Characterization of fiber/matrix interface strength: applicability of different tests, approaches and parameters. Composites Sci Technol 2005;65:149-60.

[18] Abu-Lebdeh T, Hamoush S, Heard W, Zornig B. Effects of matrix strength on pullout of steel fiber reinforced very-high strength concrete composites. Constr Build Mater 2011;25:39-46.

[19] Lamas F, Irigaray C, Oteo C, Chacon J. Selection of the most appropriate method to determine the carbonate content for engineering purposes with particular regard to marls. Eng Geol 2005;81:32-41. 